\title{
THE
}

\section{EXPLOITATIVE COMPETITION BETWEEN INVASIVE HERBIVORES BENEFITS A NATIVE HOST PLANT}

\author{
Evan L. Preisser \\ University of Rhode Island, preisser@uri.edu \\ Joseph S. Elkinton
}

Follow this and additional works at: https://digitalcommons.uri.edu/bio_facpubs

Terms of Use

All rights reserved under copyright.

\section{Citation/Publisher Attribution}

Preisser, E. L. and Elkinton, J. S. (2008), EXPLOITATIVE COMPETITION BETWEEN INVASIVE HERBIVORES BENEFITS A NATIVE HOST PLANT. Ecology, 89: 2671-2677. doi:10.1890/08-0299.1 Available at: https://doi.org/10.1890/08-0299.1

This Article is brought to you for free and open access by the Biological Sciences at DigitalCommons@URI. It has been accepted for inclusion in Biological Sciences Faculty Publications by an authorized administrator of DigitalCommons@URI. For more information, please contact digitalcommons-group@uri.edu. 


\title{
Reports
}

Ecology, 89(10), 2008, pp. 2671-2677

(C) 2008 by the Ecological Society of America

\section{EXPLOITATIVE COMPETITION BETWEEN INVASIVE HERBIVORES BENEFITS A NATIVE HOST PLANT}

\author{
Evan L. Preisser ${ }^{1,3}$ and Joseph S. Elkinton ${ }^{2}$ \\ ${ }^{1}$ Department of Biological Sciences, University of Rhode Island, Kingston, Rhode Island 02881 USA \\ ${ }^{2}$ Department of Plant, Soil, and Insect Sciences, University of Massachusetts at Amherst, Amherst, Massachusetts 01003 USA
}

\begin{abstract}
Although biological invasions are of considerable concern to ecologists, relatively little attention has been paid to the potential for and consequences of indirect interactions between invasive species. Such interactions are generally thought to enhance invasives' spread and impact (i.e., the "invasional meltdown" hypothesis); however, exotic species might also act indirectly to slow the spread or blunt the impact of other invasives. On the east coast of the United States, the invasive hemlock woolly adelgid (Adelges tsugae, HWA) and elongate hemlock scale (Fiorinia externa, EHS) both feed on eastern hemlock (Tsuga canadensis). Of the two insects, HWA is considered far more damaging and disproportionately responsible for hemlock mortality. We describe research assessing the interaction between HWA and EHS, and the consequences of this interaction for eastern hemlock. We conducted an experiment in which uninfested hemlock branches were experimentally infested with herbivores in a $2 \times 2$ factorial design (either, both, or neither herbivore species). Over the 2.5 -year course of the experiment, each herbivore's density was $\sim 30 \%$ lower in mixed- vs. single-species treatments. Intriguingly, however, interspecific competition weakened rather than enhanced plant damage: growth was lower in the HWAonly treatment than in the HWA + EHS, EHS-only, or control treatments. Our results suggest that, for HWA-infested hemlocks, the benefit of co-occurring EHS infestations (reduced HWA density) may outweigh the cost (increased resource depletion).
\end{abstract}

Key words: Adelges tsugae; biological invasions; competition; Fiorinia externa; hemlock woolly adelgid; Tsuga canadensis.

\section{INTRODUCTION}

Despite an awareness of the potential communitylevel effects of biological invasions, the nature and consequences of interactions between invasive species have received surprisingly little attention. Such phenomena are of increasing importance since interactions between invasive species should grow more common as the number of invasions increase. In addition, strong interactions between invasives appear likely because of the rapid population growth and high densities that often characterize invasive species (Mooney and Cleland 2001, Sakai et al. 2001). For example, high densities of multiple exotic herbivore species should increase the likelihood of interspecific competition; confirming this prediction, a meta-analysis found that competition was stronger between invasive herbivores than between native herbivore species (Denno et al. 1995).

Manuscript received 13 February 2008; revised 29 May 2008; accepted 3 June 2008. Corresponding Editor: M. D. Eubanks.

${ }^{3}$ E-mail: preisser@uri.edu
Although intuition suggests that multiple invasive herbivores should yield even greater impacts on native community members, other scenarios are also possible. For instance, an herbivore (invasive or otherwise) might benefit its host via apparent or exploitative competition if its presence leads to the exclusion of another herbivore whose presence is more damaging to the host plant (English-Loeb and Karban 1988). Such an outcome is especially likely if herbivore species differ greatly in their impact on plant fitness. This can happen when resource depletion is not the only (or even primary) means by which an invasive herbivore impacts its host. For example, disproportionate reductions in plant growth can occur if a herbivore facilitates secondary pathogens or injects metabolism-altering substances (Calatayud et al. 1996).

The invasive hemlock woolly adelgid Adelges tsugae (HWA) is a major threat to eastern hemlock (Tsuga canadensis) in eastern North America. HWA performs relatively poorly on hemlock species in its native range (Japan, Taiwan, and mainland China [Havill et al. 
2006]) but has far higher settlement and survival rates on eastern hemlock (McClure 1992). HWA infestations can rapidly kill even mature eastern hemlocks (McClure 1991) and substantial hemlock mortality has occurred from Virginia to Connecticut (Orwig and Foster 1998). The impact of HWA is especially striking in light of the fact that (a) HWA has little effect on the health of native host plants (McClure 1992, Havill et al. 2006), and (b) adelgid species with a similar life cycle inflict minimal damage on their native hosts (Rohfritsch 1990).

The high degree of HWA-induced hemlock mortality led to widespread fear that HWA would rapidly extirpate hemlocks from its invaded range (Orwig and Foster 1998), a prediction that appears generally accurate (reviewed in Ward et al. 2004). In New England, however, hemlock mortality appears to be occurring much more slowly than predicted (Preisser et al. 2008). Although HWA overwintering mortality undoubtedly plays a role in reducing hemlock losses in the north (Parker et al. 2002), another potential (but nonexclusive) explanation involves the recent rapid range expansion of a second introduced hemipteran, the elongate hemlock scale Fiorinia externa (EHS). Although EHS can reduce hemlock growth and may be capable of killing already-stressed trees (McClure $1980 a$ ), this insect is generally considered far less dangerous than HWA. The gloomiest predictions of hemlock mortality were made in the mid-1990s; since then, however, research assessing changes in insect density and forest health in 142 southern New England hemlock stands from 1997 through 2005 found that HWA densities have substantially declined and many hemlock stands still appear relatively healthy (Preisser et al. 2008). The same survey found dramatic increases in both the invaded range and stand-level density of EHS, which was present in 22 out of 79 sampled Connecticut stands in 1997 but had spread to all 79 stands by 2005 . The rapid rise of this second invasive herbivore, coupled paradoxically with an apparent decrease in the rate of hemlock mortality, led to the suggestion that EHS might somehow be altering tree mortality rates through its interactions with HWA (Preisser et al. 2008). Assessing the importance of the HWA-EHS interaction requires an understanding of the nature and consequences of this interaction for both invasive herbivores and their shared hemlock host.

We present the results of a multiyear experiment assessing how the co-occurrence of HWA and EHS affects their density, survival, and impact(s) on eastern hemlock growth. In light of research showing that landscape-level hemlock health has not declined as quickly as initially predicted (Preisser et al. 2008), we hypothesized that for HWA-infested eastern hemlocks, the benefit of EHS co-infestation (reduced HWA density via exploitative competition) outweighs the resourcerelated costs of EHS presence. We predicted that plant growth should be highest in the control, but that plant growth in the HWA + EHS treatment should be greater than in the HWA-only treatment but less than in the EHS-only treatment.

\section{Methods}

\section{Natural history of the system}

The hemlock woolly adelgid (HWA) is a small (1 mm adult) hemipteran native to Japan and China that was introduced near Richmond, Virginia in the 1950s; it had spread to southern New England by 1985 (McClure 1990). In the eastern United States, its invaded range now stretches from Massachusetts and New Hampshire in the north to Georgia in the south. The HWA life cycle is detailed elsewhere (McClure 1989, 1991); briefly, it is a bivoltine insect that has a holocyclic lifecycle in its native range but is obligately parthenogenetic in its invaded range. Although the early-instar "crawler" phase can move along branches or be passively dispersed between trees (McClure 1990), the adults are sessile and feed at the base of hemlock needles on ray parenchyma tissue (Young et al. 1995). High-density HWA infestations can kill mature trees in four years (McClure 1991); most trees die within 10 years of HWA colonization (Orwig et al. 2002).

The elongate hemlock scale (EHS) is a small $(1.5 \mathrm{~mm}$ adult) hemipteran that was introduced into New York City from Asia in 1908 (Sasscer 1912). In the mid-1970s, it began to rapidly expand its invaded range and has now been reported in $>14$ eastern states (Lambdin et al. 2005). It is found almost exclusively on eastern hemlock in the northeastern United States (McClure and Fergione 1977). Although EHS is univoltine in the northern portion of its invaded range and reproduces sexually, its life cycle is otherwise similar to that of HWA: overwintering adults lay eggs that hatch in late spring (one to two months later than HWA) to produce crawlers that can move actively or be dispersed passively. Crawlers settle on the underside of hemlock needles and the sessile adults feed on the mesophyll (McClure 2002). High-density EHS infestations (e.g., $>1$ scale/needle) can substantially reduce hemlock growth (McClure 1980b), and "... sometimes trees die following sustained and heavy attacks" (McClure 1980a:1392); however, we are unaware of any research documenting tree death as a direct result of EHS infestation.

In the spring, HWA crawlers settle and start to feed approximately one month before EHS crawlers arrive; HWA also has two generations a year, while EHS has only one in New England (McClure 1978). It has been suggested that the dual advantages of early settlement and an additional generation/year should allow HWA to competitively exclude EHS from their hemlock host (McClure 1997). However, the recent and rapid range expansion of EHS into HWA-dominated hemlock forests implies that this has not been the case.

\section{Experimental design}

We conducted a field experiment in which we varied herbivore species presence/absence by applying foliage 
naturally infested with HWA, EHS, or neither species to branches on uninfested hemlock trees. The experiment crossed the presence or absence of each herbivore for a total of four treatments (control, HWA only, EHS only, HWA and EHS together). The experiment took place in Cadwell Forest (Petersham, Massachusetts, USA), a research forest managed by the University of Massachusetts. Although this location is south of the current northern range limit of both HWA and EHS (Preisser et al. 2008), repeated surveys of the forest itself have found neither insect (J. Elkinton, unpublished data). Because HWA and EHS occur in forests to both the north and south of Cadwell Forest, we were given permission to carry out our experiment. We selected five mature trees ( $>15 \mathrm{~m}$ with abundant healthy foliage at ground level) in each of four sites $(>100 \mathrm{~m}$ from each other) for a total of 20 trees. Each treatment was replicated five times per tree $(5$ branches $/$ tree $\times 5$ trees $/$ site $\times 4$ sites $=100$ branches per treatment), allowing us to repeatedly sample each of the 20 trees over multiple time periods.

Because EHS crawlers emerge approximately one month after HWA crawlers, we could not apply EHSinfested foliage at the same time that the HWA-infested foliage was applied. We compensated for this by performing two rounds of branch inoculations, the first in May (an HWA-only inoculation immediately before HWA crawler emergence) and the second in June (an EHS-only inoculation immediately before EHS crawler emergence but after HWA emergence).

Inoculation protocol.-Prior to HWA crawler emergence in May 2005, we collected HWA-infested hemlock branches from Northampton, Massachusetts. We cut $20030-40 \mathrm{~cm}$ long branches with visually similar HWA densities and put each branch into a water-filled aquapic (branch and aquapic are hereafter referred to as an "inoculant"). We also created 200 "control" inoculants with uninfested foliage from Pelham, Massachusetts.

We applied five replicates of each treatment to each of the 20 trees (five trees per site, four sites) as follows. Standing to the north of each tree, we used a randomnumber table to select a treatment to apply to the nearest healthy branch $(\sim 0.5 \mathrm{~m}$ in length and $1-2 \mathrm{~m}$ above ground). We attached a single HWA-infested inoculant using twist-ties to each branch chosen for the HWA and HWA + EHS treatments. We then enclosed both the target and inoculant branch in a $60 \mathrm{~cm}$ long by $30 \mathrm{~cm}$ wide mesh sleeve $\left(1-\mathrm{mm}^{2}\right.$ mesh size; Kleantest Products, Milwaukee, Wisconsin, USA). The mesh allows ventilation but prevents crawler dispersal, encouraging emerging crawlers to settle on the uninfested branch; this protocol has been shown to maximize crawler settlement on the target branch (Butin et al. 2007). We applied an uninfested inoculant in a similar manner to each branch chosen for the control and EHS treatments, then moved clockwise around the tree until all 20 inoculant branches (five each of four treatments) were deployed on each tree.
One month after the first inoculation, we collected EHS-infested foliage from Somers, Connecticut. We replaced the previously applied foliage on each target branch with new material (EHS-infested inoculant for the EHS and HWA + EHS treatments, uninfested inoculant for the control and HWA treatments), and resealed each sleeve. Adding uninfested branches to the HWA and control treatments ensured that all branches experienced identical disturbance regimes.

Post-inoculation protocol.-Following the second round of inoculations, we allowed our experimentallycreated HWA and EHS populations to develop through the remainder of 2005. We did not survey the bagged branches during this period because both insects are so small that they could not be counted through the mesh, and opening the bags would have risked releasing crawlers and cross-contaminating our treatments. In November 2005, after all crawlers had either settled or died, we removed the mesh bags as a precaution against snow-related damage. Branches were rebagged in April 2006; we repeated this procedure in the following winter.

Data collection.-We removed one to two branches per treatment from nearly every tree in April 2006, October 2006, April 2007, and October 2007. We had initially planned to sample each treatment on each tree every sampling period. Over the 2.5-year course of the experiment, however, we lost $19 \%$ (76 out of 400) of the branches to damage from wind and/or small animals, vandalism, and inoculation failure (assessed in early March 2006). As a result, we were able to sample most (but not all) tree $\times$ treatment combinations during each sampling date.

After returning to the laboratory, we haphazardly selected five $10-\mathrm{cm}$ branchlets per branch and assessed the number of HWA and EHS per branchlet (adults and, in the October sampling, settled crawlers) and new foliage growth (cm). In April 2006 and 2007, we also determined the status (live/dead) of up to $40 \mathrm{EHS} /$ branchlet in order to calculate EHS survival over the winter period (live EHS/[live + dead EHS $]$ ); we calculated HWA survival similarly.

Statistical analysis.-Response variables for all analyses were calculated as the mean response per tree per sampling date for each treatment. Data were transformed when necessary to meet assumptions of normality. The effect of treatment on each response variable was tested using a mixed model for repeated measures analysis (Littell et al. 1996). This analytic method is recommended for use in cases where a portion of time series data is missing; in contrast, the commonly-used repeated-measures ANOVA excludes all subjects for which incomplete data is available (von Ende 2001). A two-factor (treatment and time) repeated measures design was used, and "tree" was added as a random factor nested under "treatment." Because this design is unbalanced, i.e., not every tree was sampled in every treatment $\times$ time combination, the test statistics did not follow an exact $F$ distribution. We followed the

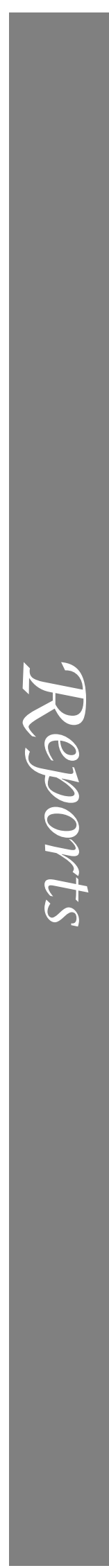




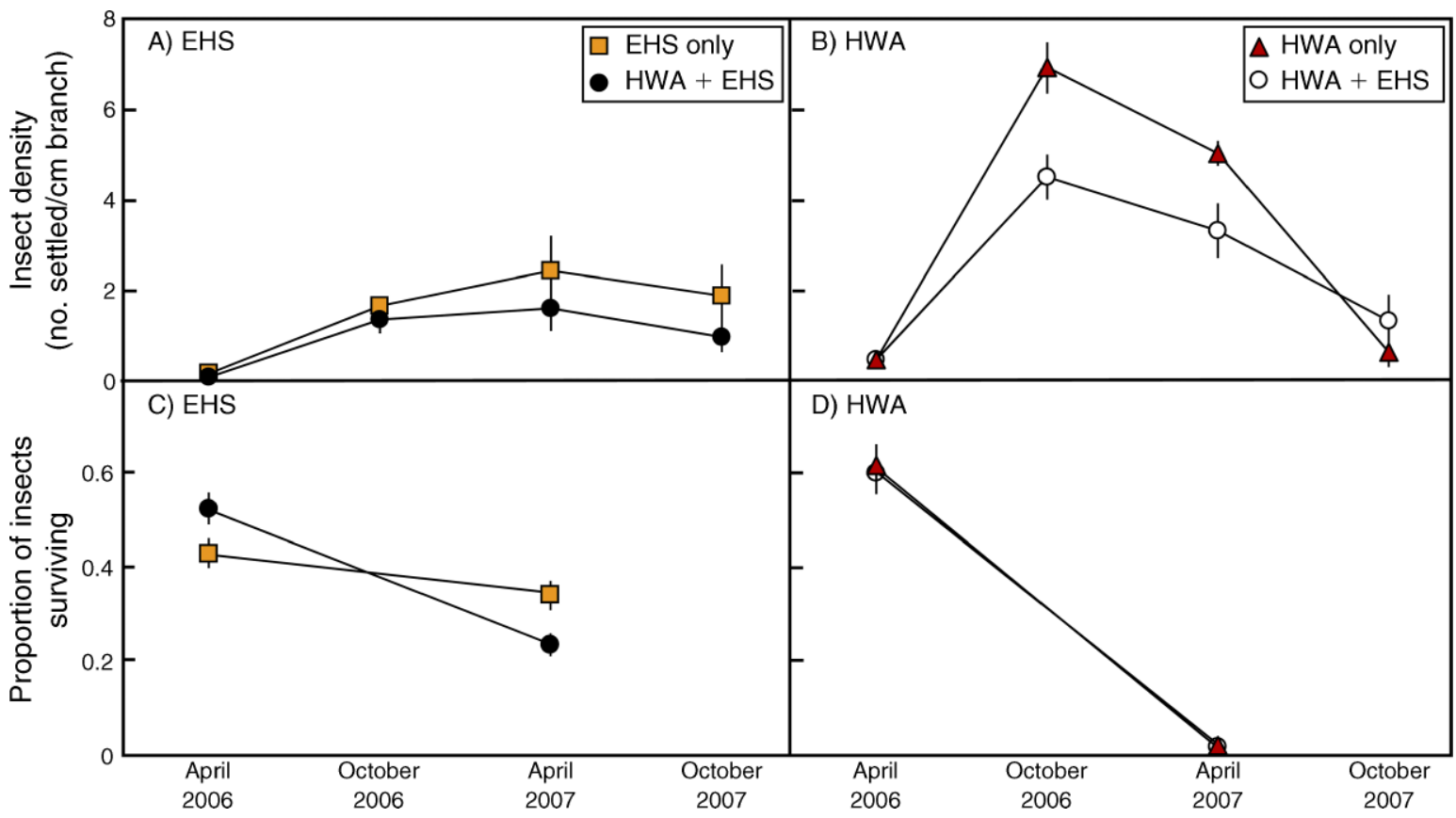

FIG. 1. Insect density and survival (mean \pm SE) over the winter period through the course of the experiment. (A) Fiorinia externa (EHS) density; (B) Adelges tsugae (HWA) density; (C) EHS survival in spring 2006 and 2007; (D) HWA survival in 2006 and 2007. Triangles, HWA-only treatment; squares, EHS-only treatment; solid circles, EHS density and survival in the HWA + EHS treatment; open circles, HWA density and survival in the HWA + EHS treatment.

recommended procedure and calculated $P$ values using the Satterthwaite approximation method to generate an $F$ approximation with fractional degrees of freedom (West et al. 2006). Site was included as a blocking variable; if nonsignificant, it was removed and the analysis re-run. Statistical analyses were performed using JMP 6.0.2 (SAS Institute 2007).

\section{RESUlts}

\section{Effects on herbivore density}

HWA density (= live plus dead individuals) was marginally affected by EHS, averaging 30\% lower in the mixed- vs. single-species treatment (Fig. 1B; treatment $\left.F_{1,40.3}=3.31, P=0.076\right)$. HWA density varied over the course of the experiment (time $F_{1,24.8}=30.3, P<0.001$ ). However, the effect of EHS presence on HWA density did not differ over time (treatment $\times$ time $F_{1,24.8}=0.99$, $P=0.33$ ). HWA survival over the winter period declined dramatically from spring 2006 to spring 2007 (Fig. 1D; time $\left.F_{1,17.8}=37.5, P<0.001\right)$ in both the single- and mixed-species treatments (treatment $F_{1,19.4}=0.003, P=$ $0.96)$. A small fraction $(\sim 5 \%)$ of control branches collected over the course of the experiment were infested with HWA, EHS, or both herbivore species; on the basis of the assumption that these branches were accidentally infested during the initial inoculations, we reclassified them as belonging to the appropriate treatment (HWAonly, EHS-only, or HWA + EHS).

EHS density was $31 \%$ lower in the presence of HWA than when grown alone (Fig. $1 \mathrm{~A}$; treatment $F_{1,28.1}=$
9.96, $P=0.004)$. Although EHS densities varied over time (time $F_{1,53.4}=23.1, P<0.001$ ), the effect of HWA on EHS density was consistent throughout the experiment (treatment $\times$ time $F_{1,53.4}=0.14, P=0.71$ ). There was no main effect of treatment on EHS survival over the winter period (Fig. $1 \mathrm{C}$; treatment $F_{1,19.8}=0.17, P=$ 0.68 ), which decreased during the experiment (time $F_{1,14.8}=13.78, P=0.02$ ). Survival over the winter period in 2006 was higher in the mixed-species treatment, while survival in 2007 was highest in the single-species treatment (treatment $\times$ time $F_{1,18.3}=6.23, P=0.022$ ).

\section{Effects on plant growth}

The amount of new foliage growth differed between treatments (Fig. 2; treatment $F_{3,61.7}=10.4, P<0.001$ ). Although foliage growth decreased over the course of the experiment in all of the treatments (time $F_{1,73.4}=$ $36.2, P<0.001$ ), foliage growth in the HWA-only treatment decreased at a faster rate than the other three treatments (Fig. 2A; treatment $\times$ time $F_{3,71.7}=9.4, P<$ 0.001 ). Across all sampling periods, plant growth in the HWA-only treatment was $27 \%$ lower than the average of the other three treatments, which did not differ from each other (Fig. 2B; Tukey's hsd with $\alpha=0.05$ ).

\section{DisCUSSION}

Our research provides evidence that an invasive herbivore can, under some circumstances, incidentally benefit its native host plant. The presence of EHS reduced the negative effect of HWA on eastern hemlock. 


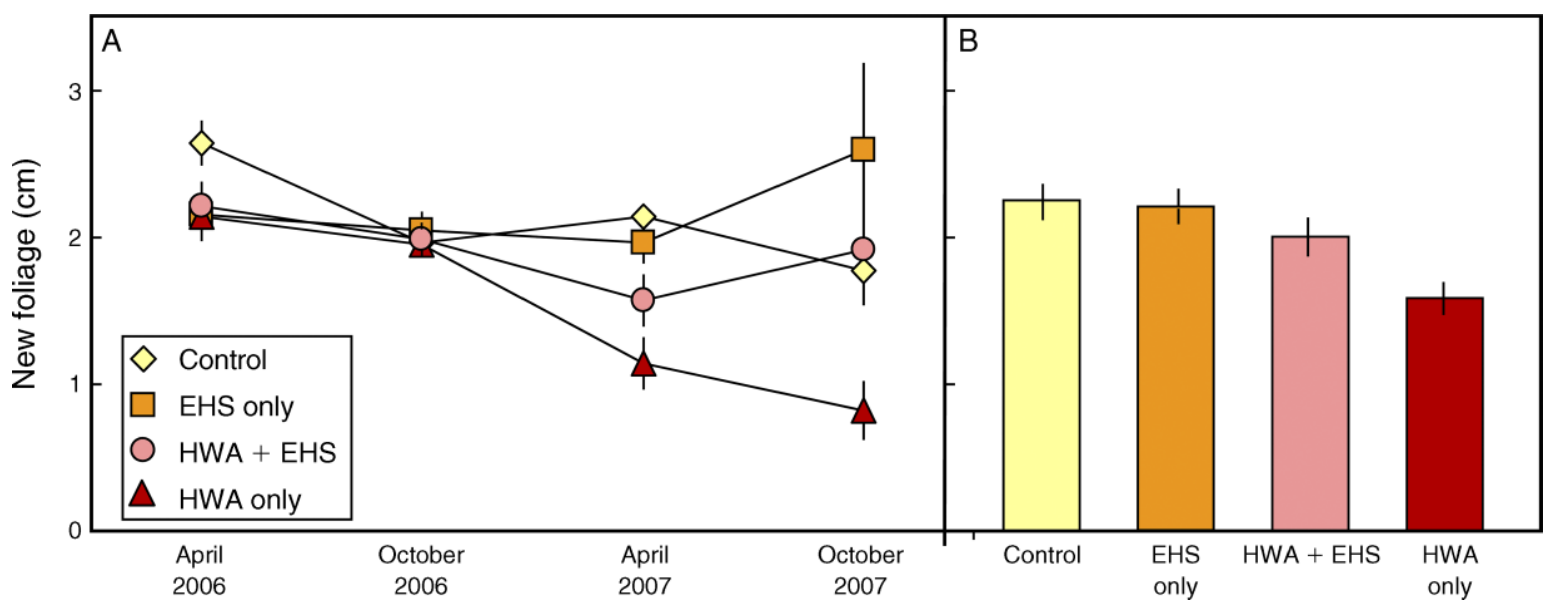

FIG. 2. New foliage growth (mean \pm SE) (A) at each of four sampling dates during the experiment and (B) across all sampling dates, by treatment. Diamonds, control treatment; squares, EHS-only treatment; circles, HWA + EHS treatment; triangles, HWAonly treatment.

This happened because co-occurrence of EHS and HWA reduced both herbivores' density by $\sim 30 \%$ (Fig. 1A, B). The reduced densities of both invasive herbivores in the HWA + EHS treatment caused less plant damage than did the high HWA density: branch growth in the HWAonly treatment was lower than in the HWA + EHS treatment (Fig. 2). EHS is not uniformly beneficial, however; in the absence of HWA, mean branch growth in the EHS-only treatment was marginally lower than in the control treatment (Fig. 2).

There are a number of potential explanations for the conditionally positive effect of an invasive herbivore on its host plant. The most likely scenario for the observed effect of EHS on HWA-infested hemlock branches is that, while both species affect the plant via resource depletion, HWA also injects chemicals during feeding that particularly affect plant health. Many phytotoxic (sensu Ryan et al. 1990) sap-feeding insects in the order Hemiptera (in particular, those formerly classified as Homoptera) induce plant metabolic changes during feeding that reduce plant defenses and cause widespread damage while locally increasing plant nutritive value (reviewed in Campbell and Eikenbary 1990, Miles 1999, Kaloshian and Walling 2005). A lack of coevolutionary history between HWA and eastern hemlock may contribute to this herbivore's toxicity. Although adelgid feeding in general is typically associated with localized damage (Miles 1999), plants that have not co-evolved with these herbivores may exhibit a hypersensitive response culminating in widespread tissue necrosis (Ryan et al. 1990).

If HWA differs from EHS in its induction of a phytotoxic response, then the plant-level benefits of EHS infestation (decreased phytotoxicity via lower HWA densities) may indeed outweigh the costs (increased total resource depletion) for HWA-colonized branches. The assumption that EHS is not similarly phytotoxic seems reasonable in light of its relatively minor effects on plant growth (Fig. 2); we are unaware of any published work addressing Fiorinia phytotoxicity. A third potential explanation for the results of our work, induced plant resistance, seems unlikely since HWA mortality did not differ between the HWA + EHS and HWA-only treatments (Fig. 1D). Finally, apparent competition between these two species also seems unlikely since effective predators of HWA and EHS are absent from southern New England (McClure and Cheah 2002), and other potentially predatory species should have been excluded from the mesh-bagged branches.

Regardless of the underlying mechanism, the HWAEHS-hemlock interaction provides a specific example of a potentially widespread phenomenon in which biological invasions are altered by other invasive species (e.g., Grosholz 2005, Lau and Strauss 2005). Such interactions should become increasingly important to native ecosystems as the number of biological invasions increase. Although interactions between invasive species may exacerbate their individual effects (e.g., the "invasional meltdown" hypothesis [Simberloff and Von Holle 1999, Grosholz 2005]), they may also serve to buffer native ecosystems: many biological control programs, for example, use invasive consumers to control other invasive species (Gruner 2005). The fact that many other phytotoxic hemipterans routinely occur at high population densities and are considered severe pests (Miles 1999) suggests that herbivore-herbivore interactions similar to the one we describe may occur in a variety of other systems.

Although our results demonstrate a beneficial effect of EHS presence on HWA-infested hemlocks, it is also possible that EHS co-infestation simply decreases the speed of hemlock mortality. We cannot exclude this possibility without carrying out whole tree-manipulations over multiple years; research of this sort is in its early stages (M. Miller-Pierce and E. L. Preisser, 
unpublished data). In the absence of a definitive answer, however, several lines of evidence suggest that the HWA-EHS interaction may slow landscape-level hemlock mortality. For example, the fact that HWA infestations kill mature hemlocks in 4-10 years (McClure 1991) led to predictions that the mid-1980's invasion of HWA into southern New England would largely extirpate hemlocks by the late 1990s (Orwig and Foster 1998). Since then, however, EHS has spread rapidly throughout southern New England, and a 2005 landscape-level survey found that despite $>15$ years of HWA presence, relatively healthy hemlock stands persist even in southern Connecticut (Preisser et al. 2008).

There were several potentially confounding factors in our experiment. Perhaps the most obvious is the fact that our experimental manipulations were done on individual branches rather than at the whole-tree scale. Logistical constraints necessitated this approach in order to achieve sufficient replication over a long time period, and we have successfully used this technique in the past (Butin et al. 2005, 2007). At the same time, however, both herbivores may have been affected by their inability to disperse and, conversely, to receive immigrants from other infested branches. While we cannot exclude this possibility, the "boom-and-bust" trends in HWA population density observed in both HWA treatments closely resemble the dynamics observed by McClure in a similar whole-tree experiment (1991). Both McClure's research and ours document a two-year cycle of rapid HWA population growth (and high survival) followed by a crash in which survival decreases dramatically. The fact that our results are qualitatively identical to those produced by similar unbagged branch manipulations (McClure 1991) suggests that the 'bag effects' on herbivore densities were not a major source of experimental error. In addition, the observed densities of both species fall well within the range of naturally occurring densities (McClure 1980a, 1991). Finally, there is the concern that hemlock branches are not functionally "autonomous," i.e., that trees re-allocate resources to stressed branches. A number of authors have suggested, however, that the branches of Tsuga and other evergreen species with indeterminate growth should be almost completely autonomous (Sprugel et al. 1991, Brooks et al. 2003); in addition, any reallocation of resources from healthy to damaged branches should reduce between-treatment differences and make our results more (rather than less) conservative.

A final concern involves the role of insect density. Our experiment utilized an additive design, meaning that if all of the "inoculant" branches had exactly the same insect densities going into the experiment, then the HWA + EHS treatment would have had twice the insect density of either single-species treatment. This approach reflected our concern that a replacement series design (attempting to hold the total herbivore density constant by halving the initial HWA and EHS densities in the combined treatment) increased the risk of failed HWA and/or EHS inoculations in the HWA + EHS treatment. Combining both approaches in a response-surface design also required a level of replication that seemed impractical over the 2.5-year course of the experiment. While our choice may have affected our early results, the long-term nature of our experiment allowed both species to settle and interact for three or more herbivore generations. Higher herbivore densities in the combined treatment should also have decreased plant growth more than in the single-species treatments; in contrast, we found that branches in the HWA + EHS treatment grew more than in the HWA-only treatment.

In addition to its conceptual interest, the interaction between these two species is of pressing conservation and management importance. HWA is spreading rapidly and killing hemlock throughout its range, from New England in the north to the Great Smoky Mountains in the south. EHS is a more recent invader whose effect on the HWA-hemlock interaction remains largely unknown (Danoff-Burg and Bird 2002, McClure 2002). Eastern hemlock is a late-successional species whose disappearance will yield long-term changes in forest structure and composition (Orwig and Foster 1998, Orwig et al. 2002) as well as significant alterations in regional carbon fluxes (Albani and Moorcroft 2004). As a consequence, research addressing the outcome and consequences of competition between these invasive herbivores may provide critically important information for management decisions at the landscape scale.

\section{ACKNOWLEDGMENTS}

This research would not have been possible without G. Boettner, A. Paradis, and G. Witkus. Discussions with J. Backer, D. Gruner, R. Karban, J. Lau, M. McClure, M. MillerPierce, and L. Ingwell greatly improved the manuscript. E. L. Preisser and J. S. Elkinton received support from USDA award 04-CA-11244225-275; E. L. Preisser also received support from NSF award DEB-0715504.

\section{Literature Cited}

Albani, M., and P. Moorcroft. 2004. Modeling the impact of hemlock loss on New England forests with the ecosystem demography model. Pages 27-28 in 15th Annual Harvard Forest LTER Symposium. Harvard Forest, Petersham, Massachusetts, USA.

Brooks, J., P. Schulte, B. Bond, R. Coulombe, J. Domec, T. Hinckley, N. McDowell, and N. Phillips. 2003. Does foliage on the same branch compete for the same water? Experiments on Douglas-fir trees. Trees: Structure and Function 17:101108.

Butin, E., A. Porter, and J. Elkinton. 2005. Adaptation during biological invasions and the case of Adelges tsugae. Evolutionary Ecology Research 87:887-900.

Butin, E., E. Preisser, and J. Elkinton. 2007. Factors affecting settlement rate of the hemlock woolly adelgid, Adelges tsugae, on eastern hemlock, Tsuga canadensis. Agricultural and Forest Entomology 9:215-219.

Calatayud, P., B. Boher, M. Nicole, and J. Geiger. 1996. Interaction between cassava mealybug and cassava: cytochemical aspects of plant cell wall modifications. Entomologia Experimentalis et Applicata 80:242-245.

Campbell, R., and R. Eikenbary, editors. 1990. Aphid-plant genotype interactions. Elsevier, New York, New York, USA.

Danoff-Burg, J., and S. Bird. 2002. Hemlock woolly adelgid and elongate hemlock scale: partners in crime? Pages 254-268 
in B. Onken, R. Reardon, and J. Lashomb, editors. Symposium on the Hemlock Woolly Adelgid in Eastern North America. U.S. Forest Service, New Brunswick, New Jersey, USA.

Denno, R., M. McClure, and J. Ott. 1995. Interspecific interactions in phytophagous insects: competition reexamined and resurrected. Annual Review of Entomology 40:297-331.

English-Loeb, G., and R. Karban. 1988. Negative interactions between Willamette mites and Pacific mites: possible management strategies for grapes. Entomologia Experimentalis et Applicata 48:269-274.

Grosholz, E. 2005. Recent biological invasion may hasten invasional meltdown by accelerating historical introductions. Proceedings of the National Academy of Sciences (USA) 102: 1088-1091.

Gruner, D. 2005. Biotic resistance to an invasive spider conferred by generalist insectivorous birds on Hawai'i Island. Biological Invasions 7:541-546.

Havill, N., M. Montgomery, G. Yu, S. Shiyake, and A. Caccone. 2006. Mitochondrial DNA from hemlock woolly adelgid (Hemiptera: Adelgidae) suggests cryptic speciation and pinpoints the source of the introduction to eastern North America. Annals of the Entomological Society of America 99:195-203.

Kaloshian, I., and L. L. Walling. 2005. Hemipterans as plant pathogens. Annual Review of Phytopathology 43:491-521.

Lambdin, P., C. Lynch, J. Grant, R. Reardon, B. Onken, and R. Rhea. 2005. Elongate hemlock scale and its natural enemies in the southern Appalachians. Pages 145-154 in R. Reardon, B. Onken, and J. Lashomb, editors. Third Symposium on the Hemlock Woolly Adelgid in the Eastern United States. U.S. Forest Service, Asheville, North Carolina, USA.

Lau, J., and S. Strauss. 2005. Insect herbivores drive important indirect effects of exotic plants on native communities. Ecology 86:2990-2997.

Littell, R., G. Miliken, W. Stroup, and R. Wolfinger. 1996. SAS system for mixed models. SAS Institute, Inc., Cary, North Carolina, USA.

McClure, M. 1978. Seasonal development of Fiorinia externa, Tsugaspidiotus tsugae (Homoptera: Diaspididae), and their parasite, Aspidiotiphagus citrinus (Hymenoptera: Aphelinidae): Importance of parasite-host synchronism to the population dynamics of two scale pests of hemlock. Environmental Entomology 7:863-870.

McClure, M. 1980a. Competition between exotic species: scale insects on hemlock. Ecology 61:1391-1401.

McClure, M. 1980b. Foliar nitrogen: a basis for host suitability for elongate hemlock scale Fiorinia externa (Homoptera: Diaspididae). Ecology 61:72-79.

McClure, M. 1989. Evidence of a polymorphic life cycle in the hemlock woolly adelgid Adelges tsugae (Homoptera: Adelgidae). Annals of the Entomological Society of America 82:5054.

McClure, M. 1990. Role of wind, birds, deer, and humans in the dispersal of hemlock woolly adelgid (Homoptera: Adelgidae). Environmental Entomology 19:36-43.

McClure, M. 1991. Density-dependent feedback and population cycles in Adelges tsugae (Homoptera: Adelgidae) on Tsuga canadensis. Environmental Entomology 20:258-264.

McClure, M. 1992. Hemlock woolly adelgid. American Nurseryman 15 March 1992:82-89.

McClure, M. 1997. Biological control in native and introduced habitats: lessons learned from the sap-feeding guilds on hemlock and pine. Pages 31-52 in D. A. Andow, D. W. Ragsdale, and R. F. Nyvall, editors. Ecological interactions and biological control. Westview Press, Boulder, Colorado, USA.

McClure, M. 2002. The elongate hemlock scale, Fiorinia externa Ferris (Homoptera: Diaspididae): a new look at an old nemesis. Pages 248-253 in B. Onken, R. Reardon, and J. Lashomb, editors. Symposium on the Hemlock Woolly
Adelgid in Eastern North America. U.S. Forest Service, New Brunswick, New Jersey, USA.

McClure, M., and C. Cheah. 2002. Important mortality factors in the life cycle of hemlock woolly adelgid Adelges tsugae in the northeastern United States. Pages 13-22 in R. Reardon, B. Onken, and J. Lashomb, editors. Symposium on the Hemlock Woolly Adelgid in Eastern North America. U.S. Forest Service, New Brunswick, New Jersey, USA.

McClure, M., and M. Fergione. 1977. Fiorinia externa and Tsugaspidiotus tsugae (Homoptera: Diaspididae): distribution, abundance, and new hosts of two destructive insects of eastern hemlock in Connecticut. Environmental Entomology 6:807-811.

Miles, P. 1999. Aphid saliva. Biological Reviews 74:41-85.

Mooney, H., and E. Cleland. 2001. The evolutionary impact of invasive species. Proceedings of the National Academy of Sciences (USA) 98:5446-5451.

Orwig, D., and D. Foster. 1998. Forest response to the introduced hemlock woolly adelgid in southern New England, USA. Journal of the Torrey Botanical Society 125:60-73.

Orwig, D., D. Foster, and D. Mausel. 2002. Landscape patterns of hemlock decline in New England due to the introduced hemlock woolly adelgid. Journal of Biogeography 29:14751488.

Parker, B., M. Skinner, S. Gouli, and H. Teillon. 2002. Cold temperatures: will they limit range expansion? Pages 269-273 in R. Reardon, B. Onken, and J. Lashomb, editors. Symposium on the Hemlock Woolly Adelgid in Eastern North America. U.S. Forest Service, New Brunswick, New Jersey, USA.

Preisser, E., A. Lodge, D. Orwig, and J. Elkinton. 2008. Range expansion and population dynamics of co-occurring invasive herbivores. Biological Invasions 10:201-213.

Rohfritsch, O. 1990. Aphid stylet movement and host-plant reaction in the case of Adelgidae on spruce. Pages 101-116 in R. Campbell and R. Eikenbary, editors. Aphid-plant genotype interactions. Elsevier, New York, New York, USA.

Ryan, J., A. Morgham, P. Richardson, R. Johnson, A. Mort, and R. Eikenbary. 1990. Greenbugs and wheat: a model system for the study of phytotoxic Homoptera. Pages 171186 in R. Campbell and R. Eikenbary, editors. Aphid-plant genotype interactions. Elsevier, New York, New York, USA. Sakai, A., et al. 2001. The population biology of invasive species. Annual Review of Ecology and Systematics 32:305-332.

SAS Institute. 2007. JMP-IN v.6.0.2. SAS Institute, Inc., Cary, North Carolina, USA.

Sasscer, E. 1912. The genus Fiorinia in the United States. USDA Bureau of Entomological Technical Services 16:75-82.

Simberloff, D., and B. Von Holle. 1999. Positive interactions of nonindigenous species: invasional meltdown? Biological Invasions 1:21-32.

Sprugel, D., T. Hinckley, and W. Schaap. 1991. The theory and practice of branch autonomy. Annual Review of Ecology and Systematics 22:309-334.

von Ende, C. 2001. Repeated-measures analysis: growth and other time-dependent measures. Pages 134-157 in S. Scheiner and J. Gurevitch, editors. Design and analysis of ecological experiments. Oxford University Press, New York, New York, USA.

Ward, J., M. Montgomery, C. Cheah, B. Onken, and R. Cowles, editors. 2004. Eastern hemlock forests: guidelines to minimize the impacts of hemlock woolly adelgid. USDA Forest Service, Morgantown, West Virginia, USA.

West, B., K. Welch, and A. Galecki. 2006. Linear mixed models: a practical guide using statistical software. CRC Press, New York, New York, USA.

Young, R., K. Shields, and G. Berlyn. 1995. Hemlock woolly adelgid (Homoptera: Adelgidae): stylet bundle insertion and feeding sites. Annals of the Entomological Society of America 88:827-835.

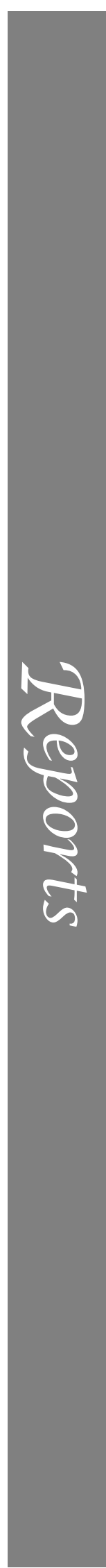

